\title{
A combination of invasive and non-invasive techniques for the study of the palette and painting structure of a copy of Raphael's Transfiguration of Christ
}

\author{
Eloísa Manzano ${ }^{* *} \oplus$, Rosario Blanc ${ }^{2}$, J. Daniel Martin-Ramos ${ }^{3}$, Giacomo Chiari ${ }^{4}$, P. Sarrazin ${ }^{5}$ and Jose Luis Vilchez ${ }^{2}$
}

\begin{abstract}
The main objective of this study is to establish an appropriate method for the characterization of the pigments, materials and structure of the paint layers in a copy of the painting the Transfiguration of Christ by Raffaello Sanzio. A multi-technique approach that combines elemental, molecular and structural analyses and involves optical microscopy (OM), scanning electron microscopy and energy-dispersive $X$-ray spectroscopy (SEM-EDX), $\mu$-Attenuated Total Reflection-Fourier Transform InfraRed ( $\mu$ ATR-FTIR), $\mu$-Raman spectrometry $(\mu R S)$ and non-invasive portable diffractometer (pXRD) was used. Our results revealed that this copy of the Transfiguration was executed with a palette, which includes white lead (cerussite and hydrocerussite), lazurite from lapis lazuli pigment, red and yellow earths (goethite, hematite and lepidocrocite), lead tin yellow, cinnabar, red lake, smalt and bone black, and fillers such as calcite, baryte (an impurity associated to some pigments), and traces of colorless powdered glass. A secondary objective of this research was the application of non-invasive in situ PXRD measurements, which do not require painting sampling and helped to confirm some inconclusive results obtained with other techniques regarding the artist's palette. The results showed the crystalline nature of all the pigments identified, which were known from ancient times and available during the 16th and 17th. Lastly, the used of ${ }^{14} \mathrm{C}$ accelerator mass spectrometry determined that the canvas date was 1451-1633 AD (with a 95\% confidence level). Although the main focus of the work was to improve the analytical methodology to better understand the artist's palette, our results will further help us to explore the authorship of the copy or the school that executed it.
\end{abstract}

Keywords: Raphael Transfiguration copy, pXRD, $\mu$ ATR-FTIR, $\mu R S$, SEM-EDX, Pigments, Painting structure

\footnotetext{
*Correspondence: emanzano@ugr.es

1 Department of Analytical Chemistry, University of Granada,

Fuentenueva s/n, 18071 Granada, Spain

Full list of author information is available at the end of the article
}

SpringerOpen

(c) The Author(s) 2021. Open Access This article is licensed under a Creative Commons Attribution 4.0 International License, which permits use, sharing, adaptation, distribution and reproduction in any medium or format, as long as you give appropriate credit to the original author(s) and the source, provide a link to the Creative Commons licence, and indicate if changes were made. The images or other third party material in this article are included in the article's Creative Commons licence, unless indicated otherwise in a credit line to the material. If material is not included in the article's Creative Commons licence and your intended use is not permitted by statutory regulation or exceeds the permitted use, you will need to obtain permission directly from the copyright holder. To view a copy of this licence, visit http://creativecommons.org/licenses/by/4.0/. The Creative Commons Public Domain Dedication waiver (http://creativeco mmons.org/publicdomain/zero/1.0/) applies to the data made available in this article, unless otherwise stated in a credit line to the data. 


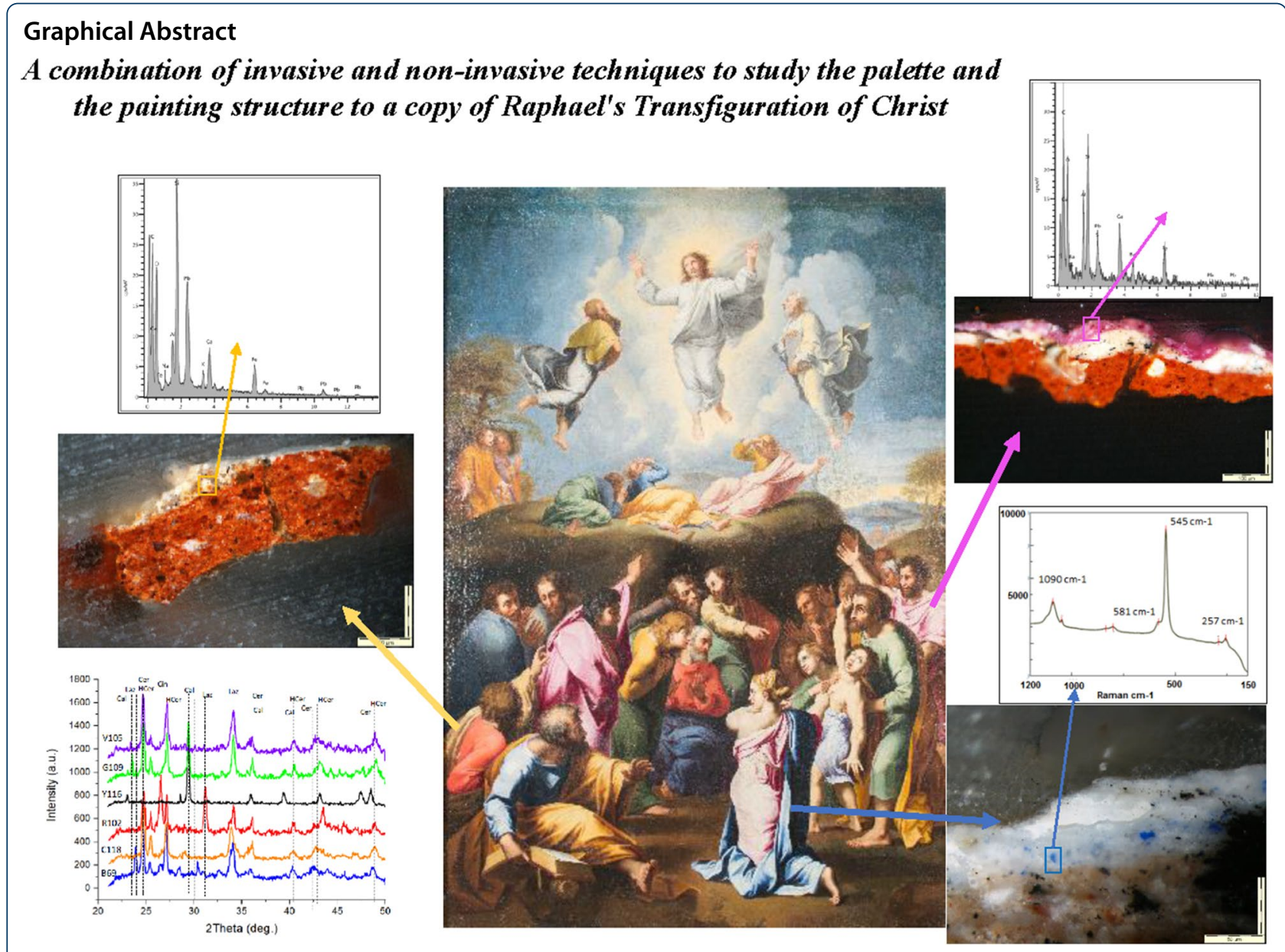

\section{Introduction}

Different analytical techniques can be used to gain an understanding of the materials and the painting techniques used by an artist. Some of these techniques include Visual and Optical Microscope observation, Attenuated Total Reflectance Fourier Transform Infrared (ATR-FTIR), Raman Spectroscopy (RS), Scanning Electron Microscopy and Transmission Microscopy (SEM/ TEM), X-ray Fluorescence Spectroscopy (XRF), X-ray Powder Diffraction (XRD), portable XRD-XRF, VIS/NIR hyperspectral imaging, and Gas Chromatography coupled to Mass Spectrometry (GC-MS), to mention some [1-10]. In Cultural Heritage studies, $\mu$-RS has proven an essential tool to differentiate the various mineralogical phases and to map the distribution of pigments within the different paint layers. Both spectroscopic techniques $\mu R S$ and $\mu$ ATR-FTIR provide useful information on molecular vibrations, but $\mu$ RS is not suitable for determination in samples with high organic content (dyes and binders). The intense fluorescent signal generated when the sample is irradiated or in pigment mixtures because the background overlaps the Raman spectrum or even completely swamps the Raman signal [11]. In addition, portable XRD (p-XRD) is a non-invasive technique that represents a suitable alternative for the determination of crystalline materials, which are found in most pigments used in the creation of paintings [12-15]. However, in the study of works of art pXRD is not frequently used in comparison to the other most common techniques mentioned above $[15,16]$.

The main goal of this study was to characterize the painting structure and to identify the pigments used in copy of The Transfiguration of Christ whose authorship is unknown. A multi-method involving invasive and noninvasive analytical techniques such as pXRD, $\mu R S, \mu$ ATRFTIR spectroscopy, conventional optical microscopy $(\mathrm{OM})$ and electronic microscopy (SEM) combined with energy dispersive X-ray (EDX) microanalysis was used for the characterization of the painting structure and identification of pigments. Radiocarbon $\left({ }^{14} \mathrm{C}\right)$ Accelerator Mass 
Spectrometry (AMS) was used for canvas dating. Paint cross-sections were first examined using conventional optical and electron microscopy in order to select the paint areas or particles that would undergo EDX analysis. Cross-section samples whose EDX analysis revealed the presence of all the paint layers underwent further $\mu \mathrm{RS}$ and $\mu$ ATR-FTIR analyses to obtain information regarding the pigments and the painting technique used by the artist. Lastly, pXRD was used for the identification and quantification of crystalline material mixtures. In addition, this non-invasive procedure does not require painting sampling and the portable instrument can be taken directly to the work of art.

The results of this study on the structure of the painting and the pigments used by the unknown artist would shed some light on a possible connection to Raphael in terms of the date of execution and authorship.

\section{Materials and methods}

\section{The painting}

The copy of the Transfiguration of Christ studied in this paper is an oil painting $(63.3 \times 93.2 \mathrm{~cm})$ on canvas which was bought from an antique dealer in Brussels and belongs to a private collection. The painting is a copy of the Transfiguration of Christ of Raphael Sanzio (1518-1520) whose original, painted on a wood panel $(405 \times 278 \mathrm{~cm})$, is in the Vatican Pinacoteca and was commissioned by Cardinal Giulio de'Medici (1515), the later Pope Clement VII. Raphael worked on the Transfiguration until his death in 1520 , but the masterpiece was left unfinished, and it is assumed that his pupil Giulio Romano finished it shortly after 1520 . Examination of the Transfiguration revealed more than sixteen incomplete areas and pentimenti. The first engraved reproduction of this masterpiece was made in 1538 and it is sometimes identified with the manner of the engraver Agostino Veneziano [17]. To our knowledge there are three known copies of the Transfiguration in Spain. The Transfiguration of Christ $(396 \times 263 \mathrm{~cm}$, oil on wood panel. Museo Nacional del Prado, Madrid, Spain) painted by Giovanni Francesco Penni, Raphael's pupil (1520-1528) [18], The Transfiguration of Christ $(405 \mathrm{~cm} \times 278 \mathrm{~cm}$, oil on wood panel. Church of Santa Eufemia, Autillo de Campos, Palencia, Spain) of unknown authorship (16th Century) [19]. The third copy is The Transfiguration of Christ $(233 \times 162 \mathrm{~cm}$, oil on canvas. Museo de la Real Academia de Bellas Artes de San Fernando, Madrid, Spain) by Domingo Álvarez Enciso (18th Century) [20]. The painting represents two consecutive events described in the Gospel according to Matthew: the upper half shows Christ's Transfiguration on Mount Tabor observed by his disciples Peter, James and John. The lower half depicts the remaining nine disciples and a boy possessed by an evil spirit (Fig. 1).
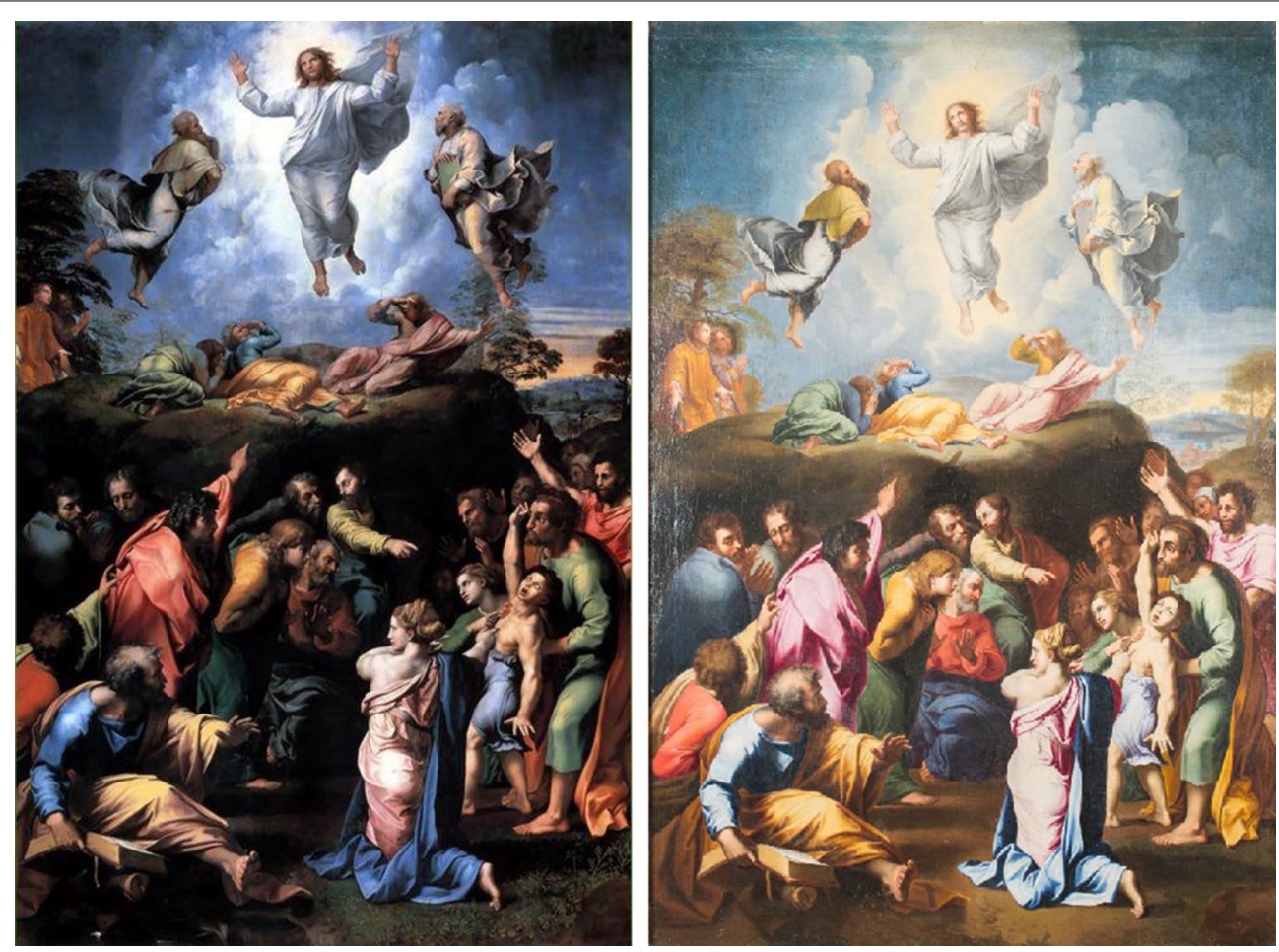

Fig. 1 The Transfiguration of Christ by Raphael in the Vatican Pinacoteca (left) and the copy of The Transfiguration studied in this paper (right) 


\section{Micro-sampling and preparation of the cross-sections}

Five representative micro-samples were obtained with the help of a scalpel. Micro-sampling sites are shown in Fig. 2a. Micro-samples were taken from non-restored areas to ensure representability and UV light was used to select the most appropriate sampling sites avoiding the dark areas, which correspond to most recent conservation interventions (Fig. 2b). Sampling was performed according to the principle of minimum invasiveness. The colored areas selected for micro-sampling were: brown from landscape at the bottom (RF-1 sample); blue from the woman's robe and sky (RF-2 and RF-5 samples, respectively); purple from the tunic of the figure on the right (RF-3 sample); and yellow from the robe of the male figure at the bottom left corner next (RF-4 sample). Each micro-sample containing the complete layer structure was embedded in Technovit resin, which was subsequently microtomed and polished with a Struer Tegrapol-15. Cross-sections were obtained for analysis.

For in situ pXRD measurements the following locations were examined: blue from the sky (69), red from the tunic of the figure on the left (102), purple from the tunic of the figure on the right (105), tunic green from the figure on the right (109), and flesh tone from the foot of the figure on the right at the bottom of the painting (118) and yellow from the apostle's cape next to the demonized boy (115) (Fig. 2a).

\section{Imaging and technical photography}

Visible images were obtained using a Canon 5D Mark-3 camera and four 500-W halogen spotlights. UV photographs were obtained with a Nikon Z-7 camera with a 24-70 zoom lens under UV illumination provided by four lamps ( $50 \mathrm{~Hz}$ Model CLE 5 Amps, $6 \times 36$ Watts).

\section{Optical microscopy and scanning electron microscopy coupled with energy dispersive $X$-ray analysis}

Cross sections images were obtained using an Olympus BX60 Microscope equipped with an LM Plan Fl 20x/0.40 objective and a DP 70 12.5 Megapixel CCD Camera. Due to the thickness of the cross sections, reflected light was used in all cases.

The Scanning Electron Microscope was a ZeissSupra 40Vp (maximum resolution: $1.3 \mathrm{~nm}$; acceleration voltage: $0.2-30 \mathrm{kV}$; software: SmartSEM) equipped with SE (InLens) and Back-scattered Electron Detector (BSE) detectors that provide morphological and chemical images, respectively. Lastly, an Aztec 2.2 EDX system equipped with an XMAX $50 \mathrm{~mm} 2$ silicon drift detector was also used.
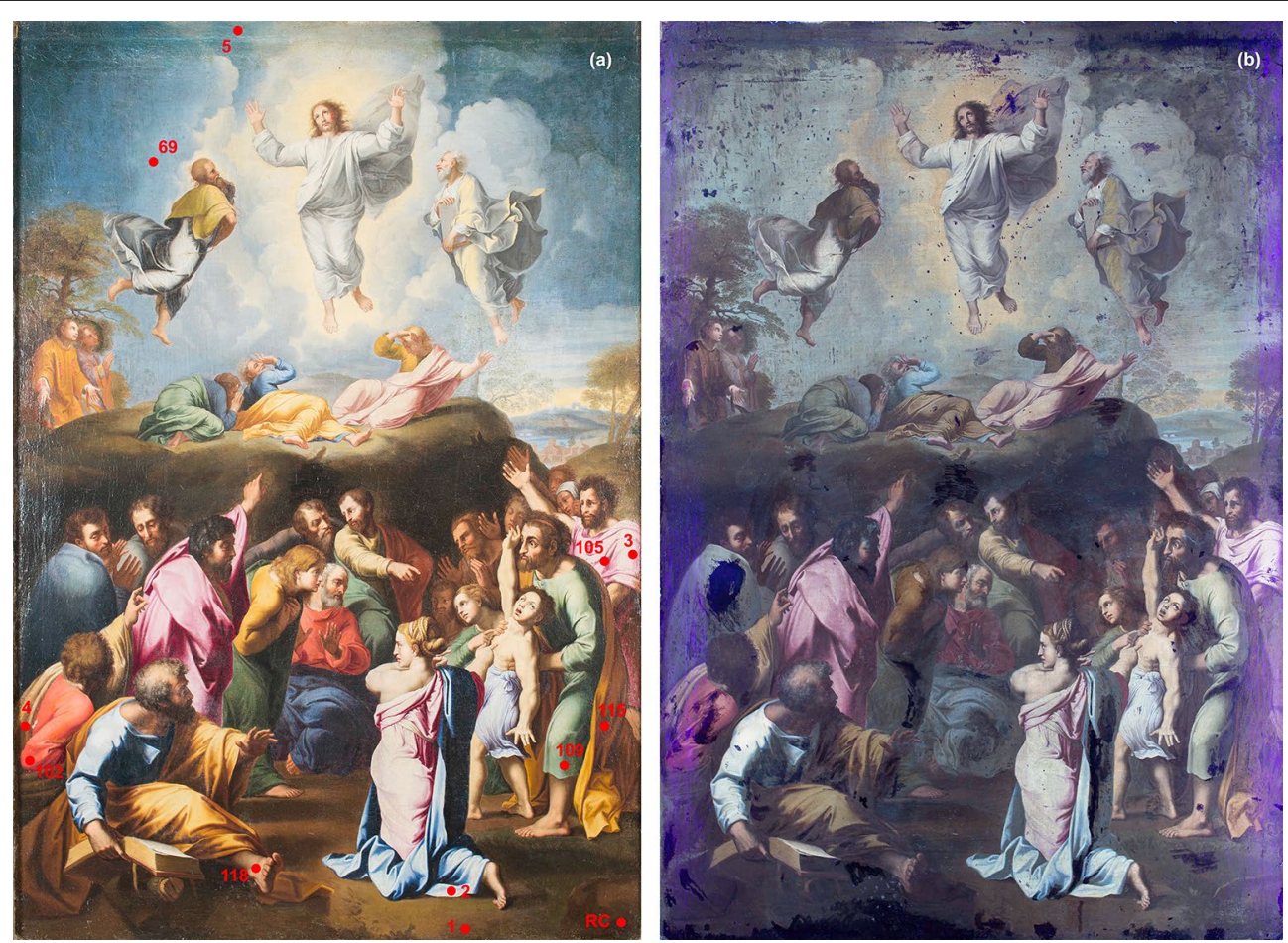

Fig. 2 Copy of The Transfiguration of Christ. a Sampling sites for cross-section analysis (RF-1 to RF-5 samples); areas examined by non-invasive pXRD $(118,116,109,102,105$ and 69 areas) and sample taken from the canvas (RC); b UV photograph 


\section{MicroRaman spectrometry}

Raman spectra of the samples were obtained with a JASCO NRS-5100 spectrometer equipped with a Peltiercooled CCD detector coupled to an OLYMPUS confocal microscope. The $520.7 \mathrm{~cm}^{-1}$ peak of a silicon standard was used for calibration. The spectrometer has two external diode lasers (solid-state source): a Nd:YAG laser with $532 \mathrm{~nm}$ wavelength (green) and a Starbright laser with $785 \mathrm{~nm}$ wavelength (red) (Torsana Laser Technologies) and $2 \mathrm{~cm}^{-1}$ resolution. Most of the Raman determinations were done with the $785 \mathrm{~nm}$ diode laser as the excitation source because it provides good Raman spectra recording with minimal fluorescence from the organic matrix or from the pigments. The $785 \mathrm{~nm}$ laser was set at $24 \mathrm{~mW}$ power, with $50 \mathrm{~s}$ acquisition time and 50 scans. The spectra of the blue pigment were acquired with the $532 \mathrm{~nm}$ laser at $3.7 \mathrm{~mW}$ power, with $50 \mathrm{~s}$ acquisition time and 6 accumulations. A color digital camera attached to the microscope $(\times 5, \times 20$ and $\times 100$ magnification $)$ allowed the visual examination of the samples and the selection of the sampling areas to collect the Raman spectra. Manager II software v. 2.08.04 was used for system control, data acquisition and data analysis. Baseline correction and slight smoothing were applied to reduce noise and facilitate data collection. The evaluation and interpretation of the Raman spectra was based on available databases of reference spectra [21, 22] including the Infrared and Raman Users Group (IRUG) database [23].

\section{Micro-attenuated Total Reflectance Fourier Transform Infrared Spectroscopy}

The FTIR spectra were acquired with a JASCO IRT7100 microscope and a JASCO 6200 infrared spectrometer with a diamond micro-ATR accessory. SPECTRA MANAGER v2 software was used for data acquisition and analysis. The ATR spectra were recorded from 600 to $4000 \mathrm{~cm}^{-1}$, with a resolution of $2 \mathrm{~cm}^{-1}$ and 200 scans.

\section{Portable diffractometer ( $p-X R D$ ) and XPowderX software}

The XRD data were collected directly on the painting surface using the Duetto portable diffractometer $[14,15]$, which does not involve any type of sample preparation. Duetto was the first commercial X-ray diffraction (XRD) and X-ray fluorescence (XRF) instrument specifically designed for Cultural Heritage. Duetto provides noninvasive in-situ XRD and XRF analysis of small areas or spots of an object of flat and convex surfaces allowing the identification of its mineralogical and chemical composition. Duetto is configured in reflection geometry and a detector collects the X-ray scattered and the energy discrimination enables simultaneous XRD and XRF measurements without invasive sampling. For good quality data, the instrument requires a sufficiently fine particles, as is typically the case with pigments. Data were processed using the XPowderX software [24]. Duetto has a $\mathrm{Cu}$ microfocus X-ray tube operated at $30 \mathrm{kV}$ and $333 \mathrm{uA}$ $(10 \mathrm{~W})$. The angular coverage of the fixed CCD detector is 20-50 deg 2theta. The integration of 2D XRD patterns results in diffractograms with a 2theta step size of $0.05 \mathrm{deg}$. The angular resolution was about $0.3 \mathrm{deg} 2$ theta FWHM at $30 \mathrm{deg}$.

\section{Accelerator mass spectrometry (AMS)}

The radiocarbon dating method was used for canvas age determination. This method depends on the decay to nitrogen of radiocarbon (carbon-14). AMS analyses were conducted at the Centro Nacional de Aceleradores $(C N A)$ in the University of Seville (Spain). For the analysis approximately $0.5 \mathrm{~cm}^{2}$ of canvas sample was obtained with a scalpel from the top right edge of the painting (RC sample), as shown in Fig. 2a. The RC sample was prepared in the CNA laboratory following the standard cleaning procedure using organic solvents, acid and bases, to obtain around $1 \mathrm{mg}$ of pure carbon sample [25].

\section{Results and discussion}

Examination of the painting surface under visible and UV light revealed the good preservation of the Transfiguration copy as well as traces of subsequent interventions in some areas (see Fig. 2b). The painting structure as well as the chemical and mineralogical composition of the paint layers were determined by OM, SEM/EDX, $\mu$ ATR-FTIR and $\mu R S$. In addition, non-invasive pXRD help to confirm the crystallographic phases of some pigment and fillers whose identification using other techniques was inconclusive. As for the results of the determinations, the layer structure (ground and pictorial layers) will be first discussed and this will be followed by the analysis of the chemical nature of the pigments, minerals and fillers present in the blue, purple, yellow, brown, red and green colors. To avoid further damage to the painting, no samples were taken of the red and green colors used in the clothes of some figures located in the central areas of the painting. Nevertheless, these areas were analysed by noninvasive pXRD.

\section{Painting layer structure}

OM examination of the cross-sections showed a redbrown ground preparatory layer, an underpainting and the pictorial layer as well as an absence of varnish (first column of Table 1). The thickness of the underpainting varied between cross-sections ranging between 10 and $70 \mu \mathrm{m}$, which means that it may have been applied only to localized areas of the painting rather than to the entire painting. The thickest underpainting layer is observed in the blue mantle of the woman (RF-2 sample) and the 
Table 1 Sample description. Color of the sampling area, estimated thickness of each layer (Layer1: ground; Layer2: underpainting; Layer3: pictorial layer); chemical elements revealed by the EDX microanalysis differentiating between major, minor and trace components, and the pigments suggested by the structural, morphological, molecular and elemental information

\begin{tabular}{|c|c|c|c|c|}
\hline \multirow[t]{2}{*}{ Sample/color } & \multirow[t]{2}{*}{ Layers (thickness) } & \multicolumn{2}{|c|}{ SEM-EDX microanalysis (elements) } & \multirow{2}{*}{$\begin{array}{l}\text { Pigments and fillers suggested by } \\
\text { OM, SEM-EDX, } \mu \text { RS, } \mu \text { ATR-FTIR and } \\
\text { pXRD }\end{array}$} \\
\hline & & Major components & Minor and trace (tr) components & \\
\hline Ground layer/red-brown & $1: 30-1650 \mu \mathrm{m}$ & $\mathrm{Fe}, \mathrm{C}, \mathrm{Ca}$ & $\begin{array}{l}\mathrm{Si}, \mathrm{Pb}, \mathrm{P}(\mathrm{tr}), \mathrm{K}(\mathrm{tr}), \mathrm{Mn}(\mathrm{tr}), \mathrm{S}(\mathrm{tr}), \mathrm{Al}(\mathrm{tr}), \mathrm{Ba}(\mathrm{tr}) \\
\mathrm{Ti}(\mathrm{tr}), \mathrm{Co}(\mathrm{tr})\end{array}$ & $\begin{array}{l}\text { Iron oxides (hematite, goethite), carbon } \\
\text { black, gypsum, white lead (cerussite } \\
\text { and hidrocerussite), bone black and } \\
\text { traces of quartz, calcite, baryte, gypsum, } \\
\text { dolomite, siderite, silicate minerals as } \\
\text { feldspar (orthoclase, microcline) and } \\
\text { lepidocrocite }\end{array}$ \\
\hline RF-1/brown area soil & $\begin{array}{l}\text { 3: pictorial layer } \\
(10-30 \mu \mathrm{m})\end{array}$ & $3: \mathrm{C}, \mathrm{Pb}$ & $\begin{array}{l}\text { 3: } \mathrm{Ca}, \mathrm{Mg}, \mathrm{S}(\mathrm{tr}), \mathrm{Al}(\mathrm{tr}) \\
\mathrm{Si}(\mathrm{tr}), \mathrm{P}(\mathrm{tr}), \mathrm{K}(\mathrm{tr}), \mathrm{Fe}(\mathrm{tr}), \mathrm{Na}(\mathrm{tr}) \mathrm{Ba}(\mathrm{tr})\end{array}$ & $\begin{array}{l}\text { 3: white lead (cerussite and hydrocerus- } \\
\text { site, iron oxides, bone black, carbon } \\
\text { black, calcite }\end{array}$ \\
\hline RF-2/blue robe & $\begin{array}{l}\text { 3: pictorial layer } \\
(30-60 \mu \mathrm{m}) \\
\text { 2: underpainting } \\
(10-70 \mu \mathrm{m})\end{array}$ & $\begin{array}{l}\text { 3: Al, } \mathrm{Si}, \mathrm{Na}, \mathrm{K} \\
2: \mathrm{C}, \mathrm{Pb}\end{array}$ & $\begin{array}{l}\text { 3: } \mathrm{Fe}, \mathrm{Pb}, \mathrm{S}, \mathrm{Co}, \mathrm{Ca}(\mathrm{tr}), \mathrm{Ba}(\mathrm{tr}) \\
\text { 2: } \mathrm{Si}, \mathrm{Fe}, \mathrm{Al}(\mathrm{tr}), \mathrm{K}(\mathrm{tr}), \mathrm{Ca}(\mathrm{tr})\end{array}$ & $\begin{array}{l}\text { 3: white lead (cerussite and hydrocerus- } \\
\text { site, lapis lazuli, smalt } \\
\text { 2: white lead (cerussite and hydrocerus- } \\
\text { site), carbon black }\end{array}$ \\
\hline RF-3/purple tunic & $\begin{array}{l}\text { 3: pictorial layer } \\
(10-40 \mu \mathrm{m}) \\
\text { 2: underpainting } \\
(20-70 \mu \mathrm{m})\end{array}$ & $\begin{array}{l}\text { 3: } \mathrm{C}, \mathrm{Pb}, \mathrm{Al} \\
2: \mathrm{C}, \mathrm{Pb}\end{array}$ & $\begin{array}{l}\text { 3: Fe,Ca,Si(tr),S(tr),K(tr), Ba(tr),Mn(tr) } \\
\text { 2: Fe,Ca(tr),Si(tr),Al(tr) }\end{array}$ & $\begin{array}{l}\text { 3: red lake, white lead (cerussite and } \\
\text { hydrocerussite) } \\
\text { 2: white lead (cerussite and hydrocerus- } \\
\text { site), carbon black }\end{array}$ \\
\hline RF-4/yellow robe & $\begin{array}{l}\text { 3: pictorial layer } \\
(10-50 \mu \mathrm{m}) \\
\text { 2: underpainting } \\
(10-40 \mu \mathrm{m})\end{array}$ & $\begin{array}{l}\text { 3: } \mathrm{C}, \mathrm{Pb} \\
2: \mathrm{C}, \mathrm{Pb}\end{array}$ & $\begin{array}{l}\text { 3: } \mathrm{Ca}, \mathrm{Fe}, \mathrm{Si}(\mathrm{tr}), \mathrm{Al}(\mathrm{tr}) \\
\text { 2: } \mathrm{Fe}(\mathrm{tr})\end{array}$ & $\begin{array}{l}\text { 3: white lead (cerussite and hydrocer- } \\
\text { ussite), iron oxides (goethite), lead tin } \\
\text { yellow } \\
\text { 2: white lead (cerussite and hydrocerus- } \\
\text { site), carbon black }\end{array}$ \\
\hline RF-5/blue sky & $\begin{array}{l}\text { 3: pictorial layer } \\
(10-60 \mu \mathrm{m})\end{array}$ & $\begin{array}{l}\text { 3: blue particle: } \mathrm{Si}, \mathrm{Al}, \\
\text { 3: black area: } \mathrm{C}, \mathrm{Pb}\end{array}$ & $\begin{array}{l}\text { 3: blue particle: Co,Pb, Mg, } \\
\text { Fe(tr),K(tr),Na(tr), S(tr),Zn(tr),Ca(tr) } \\
\text { 3: black area: Ca,Si,P,Mg,Al(tr), } \\
\text { Fe(tr),K(tr) }\end{array}$ & $\begin{array}{l}\text { 3: blue particle: } \\
\text { lapis lazuli, smalt } \\
\text { 3: black area: } \\
\text { carbon black, bone black, } \\
\text { white lead (cerussite and hydrocerus- } \\
\text { site) }\end{array}$ \\
\hline
\end{tabular}

purple tunic (RF-3 sample). In contrast, the underpainting is very thin in the sample from the yellow robe (RF-4 sample) and its color seems to be impregnated with the red-brown color used in the ground painted below. In samples RF-1 and RF-5, collected from the very edge of the painting, where the underlayer is very fine. In the pictorial layer, blue, black and red pigment particles were mixed with a white color to provide the lighter coloration and tone observed in blue and purple areas, respectively. The color of the sampling area estimated thickness of each layer, elemental composition and crystallographic phases are listed in Table 1 . The last column shows the pigments suggested by the structural, morphological, molecular and elemental information provided by the multi-technique approach (OM, SEM-EDX, $\mu$ RS, $\mu$ ATRFTIR and $\mathrm{pXRD)}$.

\section{Ground layer}

The combination of the morphological observations and the results from the EDX, $\mu R S, \mu$ ATR-FTIR and pXRD analyses showed that the red-brown ground was very similar in composition in all the areas sampled. This redbrown ground can be found in works of art executed in Europe during the sixteenth-eighteenth centuries [26]. The first row in Table 1, shows the results obtained for the ground layer. Its thickness varied between 30 and $1650 \mu \mathrm{m}$ depending on the area analyzed. The EDX microanalysis revealed the presence of Fe associated with $\mathrm{Si}, \mathrm{Al}$ and traces of other elements, which indicates the presence of earth pigments (red and yellow pigments). Raman bands at 221 vs, 289 vs, 406 m, 490 w and 603 $\mathrm{w} \mathrm{cm}{ }^{-1}$ are consistent with the presence of iron oxides (goethite $(\alpha-\mathrm{FeOOH})$, hematite $\left(\alpha-\mathrm{Fe}_{2} \mathrm{O}_{3}\right.$ and lepidocrocite $\gamma-\mathrm{FeO}(\mathrm{OH})$ ), and traces of clay minerals suggest the presence of aluminosilicate minerals. Calcite $\left(1086 \mathrm{~cm}^{-1}\right)$, white lead $\left(2 \mathrm{PbCO}_{3} \cdot \mathrm{Pb}(\mathrm{OH})_{2}\right)\left(1049 \mathrm{~cm}^{-1}\right)$ and carbon black (1311 and $1580 \mathrm{~cm}^{-1}$ ) were also identified. Iron oxides and clay minerals provide the ground layer with the red-brown color, whose variations are related to the amount and nature of the iron oxide chromophore (yellow goethite and red hematite). In addition, traces of baryte $\left(\mathrm{BaSO}_{4}\right)$ were suggested by the 
distribution map of $\mathrm{Ba}$, distribution map of $\mathrm{S}$ (Fig. 3b) and the elemental EDX spectrum in the spot indicated (Fig. 3c). Traces of gypsum $\left(\mathrm{CaSO}_{4} \cdot 2 \mathrm{H}_{2} \mathrm{O}\right)$ and transparent glass particles with traces of $\mathrm{Mn}$ were also detected in the ground layer (Fig. 3f). According to the literature [30-34], in the Italian Renaissance ground layers were often enriched with colorless glass particles with traces of $\mathrm{Mn}$ as an additive to speed up the drying of the oil paint.

Fine particles of black pigment were observed in the cross-section microphotographs of both the pictorial layer and the ground layer (Figs. 3a, 4a). The presence of $\mathrm{C}$ is supported by the elemental EDX microanalysis and Raman spectrum whose bands (1311 and $1580 \mathrm{~cm}^{-1}$ ) correspond with those available in databases for standard pigments [22, 23] (Fig. 4d). However, these techniques cannot differentiate between different black pigments, most of which are organic compounds. An exception is bone black, $\left(\mathrm{Ca}_{5}(\mathrm{OH})\left(\mathrm{PO}_{4}\right)_{3}\right.$ and $\mathrm{C}$, whose presence is supported by the detection of $\mathrm{Ca}$ and traces of $\mathrm{P}$ by EDX microanalysis of black particles in the ground layer. The EDX microanalysis was carried out in the black box area in Fig. 4a. The elemental distribution EDX map (Fig. 4b) and the EDX spectrum (Fig. 4c) from the sky area show the simultaneous presence of $\mathrm{P}, \mathrm{Ca}$ and $\mathrm{C}$ in a dark particle. Ca probably comes from calcium phosphate and from the traces of calcium carbonate detected. This finding suggests the use of an amorphous carbon black mixed with some bone black pigment $\left[\mathrm{Ca}_{5}(\mathrm{OH})\left(\mathrm{PO}_{4}\right)_{3}\right]$ in the ground area of the painting. The use of bone black pigment cannot be confirmed by Raman analyses due to the absence of a band around $965 \mathrm{~cm}^{-1}$, caused by the phosphate stretching mode (hydroxyapatite). As expected, since the amounts of phosphate are usually at the trace level, no significant FTIR bands that could be assigned to phosphate were found.

Diffraction data were collected directly from the painting surface using the Duetto portable diffractometer. Table 2 shows the primary pigments found in the selected

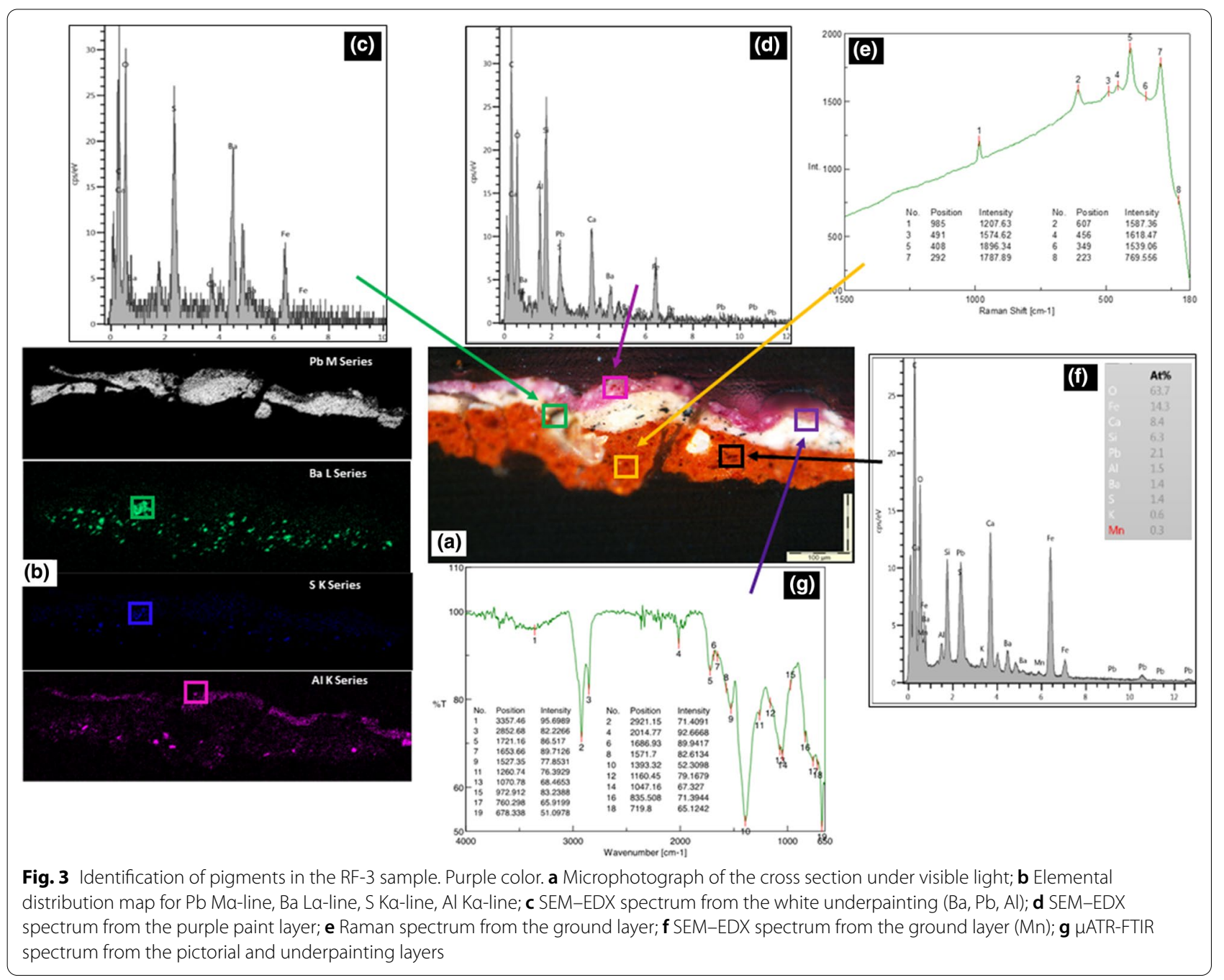




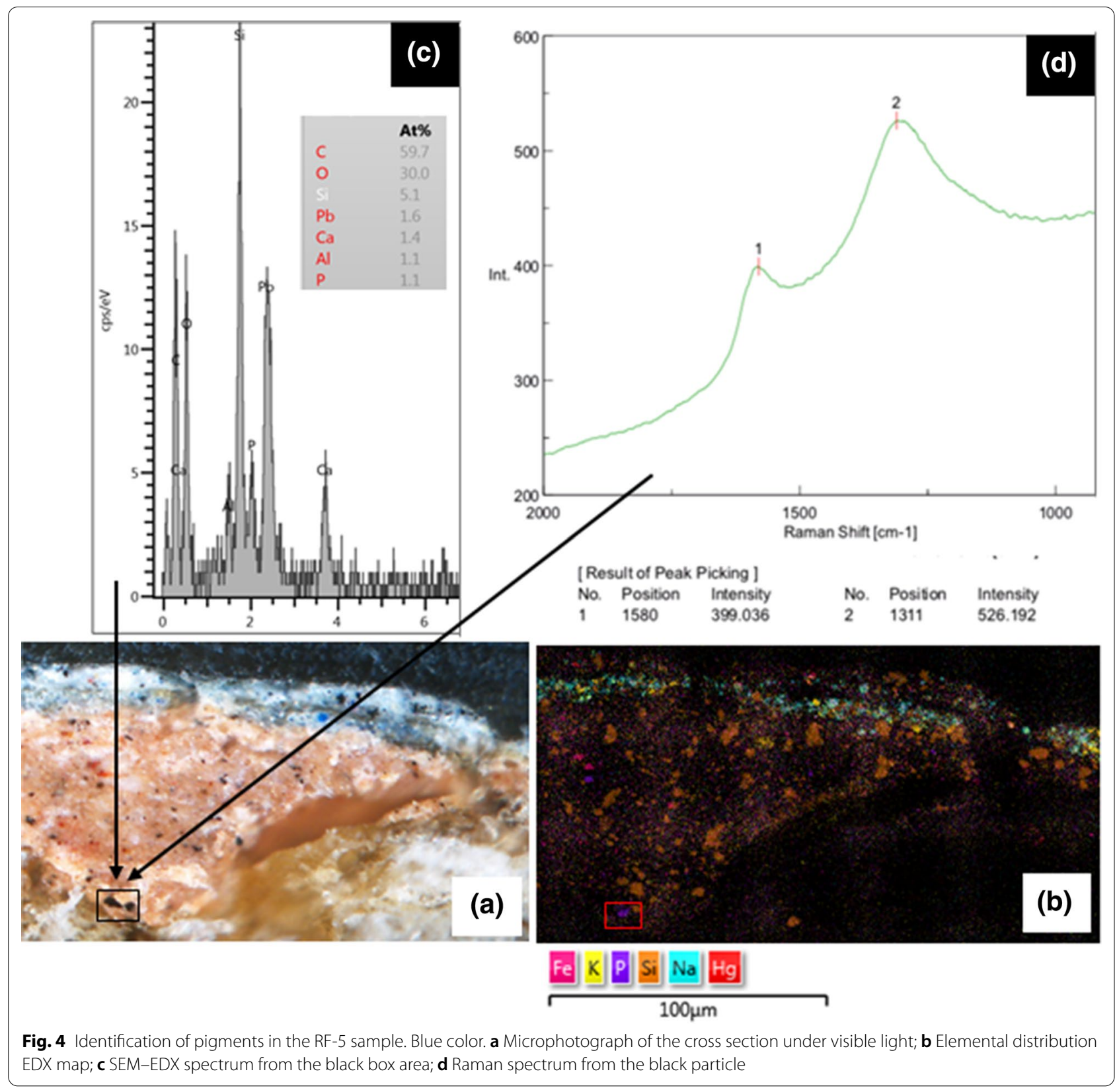

Table $2 \%$ Relative Pattern Intensity Ratio (PIR) of pigments in selected areas

\begin{tabular}{|c|c|c|c|c|c|c|c|c|}
\hline Sample & Cerussite & Hydrocerussite & Calcite & Lead Tin Yellow & Lazurite & Lepidocrocite & Cinnabar & Graphite \\
\hline V105 & $36.8 \pm 2.8$ & $30.2 \pm 5.3$ & - & - & - & $15,2 \pm 2.9$ & $17.8 \pm 6.8$ & - \\
\hline Y111 & $15.7 \pm 5.0$ & $10.5 \pm 5.4$ & $8.8 \pm 4.9$ & $38.6 \pm 1.5$ & - & $10.9 \pm 2.9$ & $10.5 \pm 5.3$ & $5.1 \pm 5.4$ \\
\hline G109 & $21.5 \pm 3.0$ & $19.5 \pm 3.4$ & $22.0 \pm 1.7$ & $21.9 \pm 3.3$ & - & $9.0 \pm 4.7$ & - & - \\
\hline R102 & $19.8 \pm 5.4$ & $20.3 \pm 4.8$ & - & - & - & $14.0 \pm 3.2$ & $32.6 \pm 2.9$ & $13.3 \pm 4.8$ \\
\hline C104 & $46.0 \pm 1$ & $44.6 \pm 2.4$ & - & - & - & & $3.3 \pm 2.6$ & $6.1 \pm 4.9$ \\
\hline $\mathrm{C} 118$ & $46.5 \pm 2.6$ & $32.8 \pm 4.5$ & - & - & - & $20.3 \pm 4.3$ & $3.4 \pm 2.5$ & - \\
\hline B69 & $36.7 \pm 3.7$ & $44.5 \pm 2.6$ & - & - & $18.8 \pm 5.4$ & - & - & - \\
\hline
\end{tabular}


areas analyzed by pXRD. Thus, in the blue areas, lapis lazuli $(18.8 \pm 5.4 \%)$ is clearly observed. In the yellow, tin and lead yellow $(38.6 \pm 1.5 \%)$. In the green tin and lead yellow $(21.9 \pm 3.3 \%)$ and in the red cinnabar $(32.6 \pm 2.9 \%)$.

All the diffractograms as well as the stratigraphic cross sections of the preparation layer reveal the presence of cerussite and hydrocerussite. Since the XRD analysis can not determine if these lead carbonates are part of the preparation layers or were by the artist to achieve light colors, their presence in the preparation layer has been verified by the different techniques. The mineralogical phases identified are interpreted together with stratigraphic observations, clearly visible in both $\mathrm{OM}$ and BSE cross-sectional images. XRD analysis revealed the presence of calcite, cerussite and hydrocerussite as well as traces of gypsum, quartz, dolomite, siderite, silicate minerals such as feldspar (orthoclase, microcline) and lepidocrocite, found in all the samples collected from the ground areas. Nevertheless, the analyses are strongly determined by the top layer composition.

\section{Underpainting}

Conventional OM examination revealed a white or light underpainting that was used to lighten the blue, purple and yellow colors in samples RF-2, RF-3 and RF-4, respectively. In the RF-4 sample, the underpainting is very thin, and the coloration is similar to that of the ground layer but more yellowish. The presence of a band at $1055 \mathrm{~cm}^{-1}$ ( $\left(\mathrm{C} 1 \mathrm{CO}_{3}{ }^{2-}\right.$ symmetric stretching vibrations) in the RS analysis confirms an abundance of lead carbonate in the underpainting layer.

\section{Pictorial layer: brown area (RF-1 sample)}

Conventional OM analysis revealed a dark ochre pictorial layer in the red-brown ground area at the bottom of the painting that is hardly distinguishable from the fine light ochre underpainting and ground layer on which it was applied. The pictorial layer in the RF-1 sample shows abundant $\mathrm{Pb}$, from white lead pigment, and $\mathrm{C}$ (Table 1 ). The fluorescence interference observed in the Raman spectra obtained from this area suggests the presence of a high content of organic compounds used as binder which could overlap the presence of C. Raman spectra allowed the identification of white lead $\left(1050 \mathrm{~cm}^{-1}\right)$, calcite $\left(1087 \mathrm{~cm}^{-1}\right)$ and some characteristic Raman bands of iron oxide/hydroxide mixtures such as red earths and hematite $\left(228 \mathrm{~s}, 293 \mathrm{vs}, 409 \mathrm{~m}, 608 \mathrm{~m}, 1298 \mathrm{w} \mathrm{cm}^{-1}\right)$ in some red particles probably coming from the ground layer beneath.

\section{Pictorial layer: blue area (RF-2 and RF-5 samples)}

Samples of blue color from two different areas of the painting were taken from the sky (RF-5 sample) and from the robe of the woman at the bottom of the painting (RF-2 sample). Two layers over the ground layer can be clearly observed in RF-2 sample cross section (Fig. 5a). The artist applied a white-yellowish underpainting over the red-brown ground layer which shows abundant black particles and some blue particles, clearly visible in both $\mathrm{OM}$ and BSE cross-sectional images. Nevertheless, the blue color from the sky area (RF-5 sample) was applied on a very thin underpainting layer on the red-brown ground. Many blue particles of different shapes were distributed throughout the thickness of the outer blue layer in both RF-2 and RF-5 samples. Some of those particles show the typical conchoidal shape, occasionally concave edges with a size $(20-70 \mu \mathrm{m})$ and morphology characteristic of smalt (cobalt-based blue pigment)) [27-29, 34] The distribution of $\mathrm{Si}, \mathrm{Co}, \mathrm{K}$ and $\mathrm{S}$ in the EDX spectra (Table 1) is consistent with the presence of smalt particles in the blue layer from the RF-2 sample. A selected EDX spectrum is shown in Fig. 5b. In addition, the SEM-EDX analysis revealed the presence of $\mathrm{Pb}$ in the white particles and $\mathrm{Na}, \mathrm{Al}$, and $\mathrm{Si}$ in other blue particles seen in the pictorial layer of the RF-2 sample, which may correspond to white lead and lapis lazuli (sulphur-containing aluminum silicate, $\mathrm{Na}_{8}\left[\mathrm{A1}_{6} \mathrm{Si}_{6} \mathrm{O}_{24}\right] \mathrm{Sn}$ ) (Fig. 5c) [35]. The amount of backscattered electrons of the $\mathrm{Pb}$-containing pigment is higher than that of $\mathrm{Si}, \mathrm{Na}$ and $\mathrm{Al}$, which are also observed in the EDX spectra. Consequently, $\mathrm{C}$ and $\mathrm{Pb}$ are the main elements of the blue pictorial layer in the RF-2 sample.

To confirm the presence of lapis lazuli the $530 \mathrm{~nm}$ wavelength was finally used to obtain the Raman spectra of the blue particles because of its better band discrimination. Figure $6 \mathrm{~d}$ shows a selected Raman spectrum from the blue pictorial layer of the woman's robe (RF-2 sample) acquired at 150 and $1.200 \mathrm{~cm}^{-1}$, with $258,548,822$ and $1090 \mathrm{~cm}^{-1}$ bands. Although the bands at $258 \mathrm{~cm}^{-1}$ and $822 \mathrm{~cm}^{-1}$, characteristic of lapis lazuli, are scarcely reported in the literature, our results showed one band at $258 \mathrm{~cm}^{-1}$ and a weak but wide band at $800 \mathrm{~cm}^{-1}$. XRD results support lazurite from Lapis Lazuli pigment found on the sky area (B-69 site) (Table 2) in addition to cerussite, hydrocerussite and calcite that most likely come from the ground layer.

\section{Pictorial layer. Purple area (RF-3 sample)}

The OM and BSE images from the RF-3 sample crosssection revealed that the artist also applied a broad white underpainting over the ground layer in the purplecolored area (Fig. 3a). The EDX microanalysis (Al, Ca, $\mathrm{C}$ and $\mathrm{Pb}$ ) (Fig. $3 \mathrm{~d}$ ) and the $\mathrm{Pb}$ and $\mathrm{Al}$ distribution maps (Fig. 3b) showed that a red lake with an aluminum-based substrate [36] was applied over the pure white lead underpainting to obtain the purple color in the tunic (RF-3). Varying proportions of red lake and some blue 


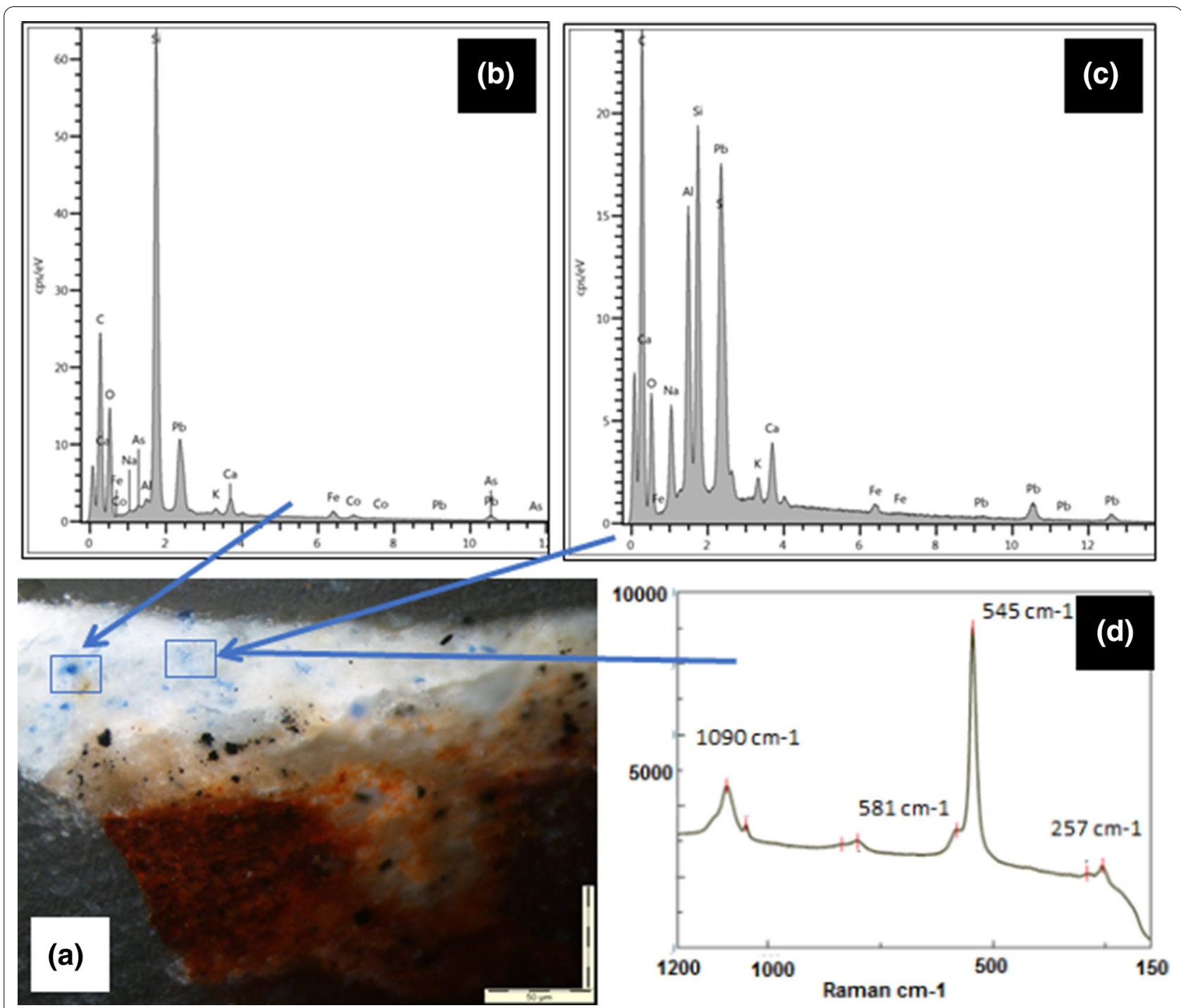

Fig. 5 Pigment identification in the RF-2 sample. Blue color. a Microphotograph of the cross section under visible light; $\mathbf{b}$ Smalt SEM-EDX spectrum c Lapis lazuli SEM-EDX spectrum; d Raman spectrum of blue particle (lapis lazuli)

particles mixed with white fillers (calcite, barium sulphate) and white lead and carbon-based black pigments used for the purple color were often used by Raphael according to the literature [27]. In addition, trace levels of $\mathrm{Mn}$ and $\mathrm{C}$ in the dark areas indicate the presence of additional compounds that were probably used for shadowing the purple and blue robes of some figures. The XRD analysis revealed the presence of traces of lead tin yellow pigment in the purple color despite Sn was not revealed by the EDX microanalysis in this area [16]. For this reason, this might be an impurity from the painting tools in the purple color. Consequently black, red, blue and yellow particles also mixed with calcite or white lead are responsible of the purple color.
In contrast, no Raman spectra from the purple tunic was obtained with any of the excitation lines used (780 $\mathrm{nm}$ and $530 \mathrm{~nm}$ ) because the intense fluorescence generated by the organic red lake and organic binders swamp the Raman signal [11]. In some spots from the purple area, was used to identify the characteristic IR bands of red. The results of $\mu$ ATR-FTIR can be difficult to interpret due to numerous vibrational bands in the $1750-1150 \mathrm{~cm}^{-1}$ range and to the overlapping bands from organic binders $\left(1730-1600 \mathrm{~cm}^{-1}\right)$ and from white lead pigment $\left(1389 \mathrm{~cm}^{-1}\right)$ [37, 38]. Thus, the $\mu$ ATR-IR spectra from the outer layer exhibited the $v\left(\mathrm{CH}_{2}\right)$ and $v\left(\mathrm{CH}_{3}\right)$ stretching bands at 2921 and $2852 \mathrm{~cm}^{-1}$ related to the presence of hydrocarbon chains $(\mathrm{C}-\mathrm{H})$ from the 


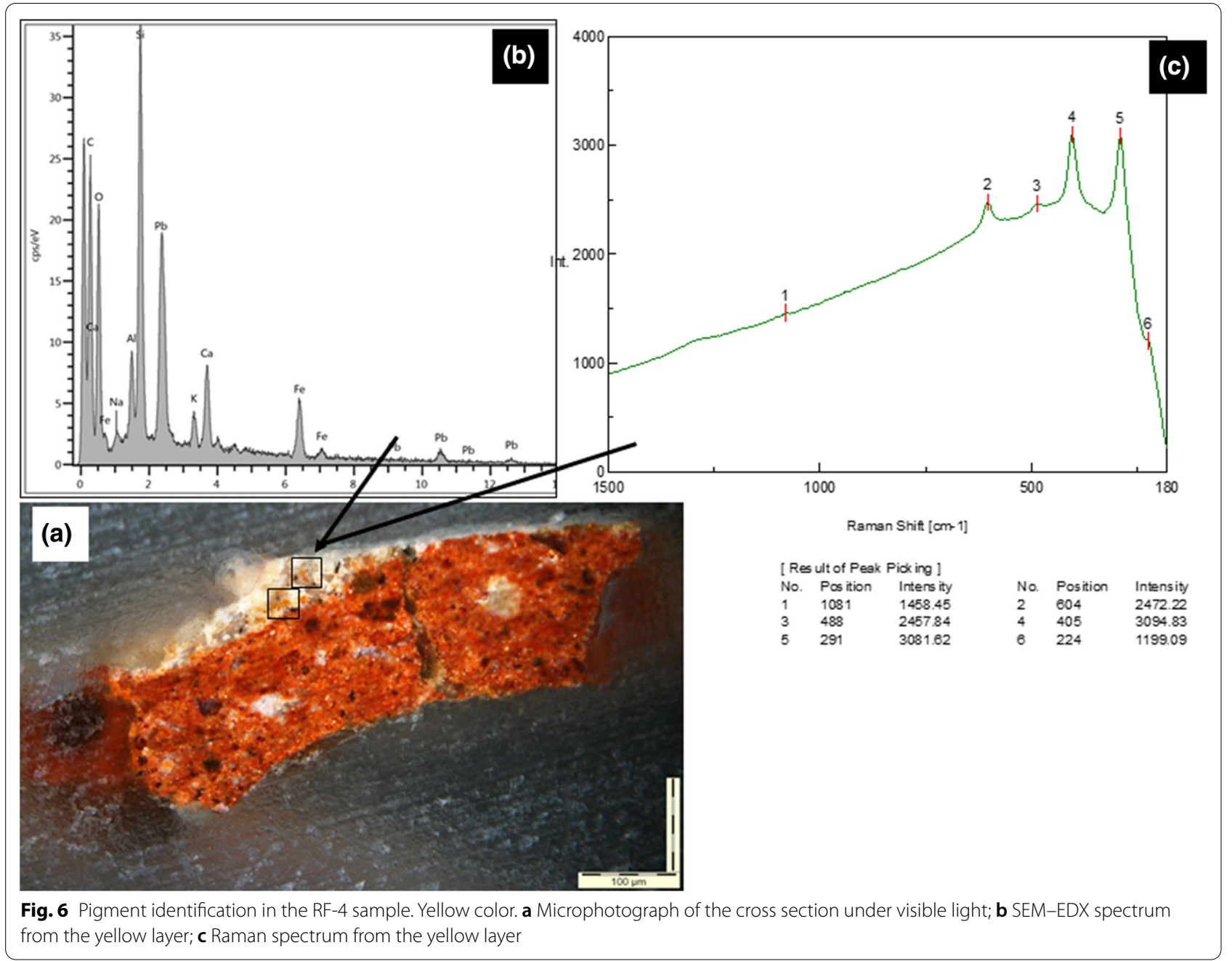

oil binding medium and the organic dyes. In addition, the $\mathrm{C}=\mathrm{O}$ stretch at $1721 \mathrm{~cm}^{-1}$ and at 1686, 1653, 1571 and $1527 \mathrm{~cm}^{-1}$ suggest some type of organic dye. Nevertheless, the identification of red lakes by $\mu$ ATR-FTIR analysis was inconclusive.

\section{Pictorial layer. Yellow area (RF-4)}

The OM image from the cross-section of RF-4 sample revealed a thin yellowish layer that is hard to differentiate from the fine light ochre underpainting on the redbrown ground layer on which it was applied (Fig. 6a). The SEM-EDX microanalysis revealed the presence of abundant $\mathrm{Pb}$ and less abundant Fe and Ca (Fig. 6b). Raman spectra showed bands characteristic of white lead, red iron oxides and oxyhydroxides with other minerals such as calcite and traces of clay minerals $\left(221 \mathrm{sh} \mathrm{cm}^{-1}, 288 \mathrm{vs}\right.$ $\left.\mathrm{cm}^{-1}, 402 \mathrm{vs} \mathrm{cm}^{-1}, 489 \mathrm{w} \mathrm{cm}^{-1}, 602 \mathrm{~s} \mathrm{~cm}^{-1}, 1085 \mathrm{w} \mathrm{cm}^{-1}\right)$. Figure 6c shows a Raman spectrum from the yellow area. The SEM-EDX analysis showed the presence of yellow earth, carbon black and some particles of smalt and lapis lazuli, all mixed with abundant white lead. The elemental mapping supported the presence of abundant $\mathrm{Fe}$ in the pictorial layer which is consistent with the use of goethite as a pigment. Lead tin yellow was identified by noninvasive XRD analysis in the yellow area rich in calcite (Table 2). Lead tin yellow was widely used by Renaissance artists. [27].

Pictorial layer: red, green and flesh tone areas (R-102, G-109 and C-104 sites)

In order to minimize damage to the painting, no samples were taken from the central areas. Consequently, the composition of the crystalline pigments in the red, green and flesh tone areas was obtained through pXRD measurements directly taken from the painting surface. Since vermilion was not detected by EDX or $\mu R S$ on the red draperies (R-102), pXRD measurement allowed to identify the red pigment mercury sulfide $(\alpha-\mathrm{HgS})$, or cinnabar in its natural form (Table 2). On the flesh tones of the figure (C-118) cinnabar was found mixed with cerussite, 
azurite and lazurite. The green tones from the robe of the figure on the right (G-109) consist of mixtures of cerussite, hydrocerussite, lazurite and an unknown yellow pigment that provides the green color. This yellow pigment might be the same lead tin yellow pigment used in the yellow areas, but it has not been confirmed.

\section{Canvas radiocarbon dating}

AMS measurement were used for canvas dating [39]. The results of the $14 \mathrm{C}$ dating are as follows: CNA5281.2.1, Radiocarbon Age: $360 \pm 25 \quad \mathrm{BP}, \quad \delta 13 \mathrm{C}=-26.0 \pm 1.5$ per mil. Radiocarbon age was calibrated $(2 \sigma)$ giving:1451-1526 AD (55.3\%) and 1555-1633 AD (44.7\%). In order to simplify the discussion, both ranges can be combined which suggests the canvas can be dated to 1451-1633 AD with a 95\% confidence level.

\section{Conclusion and future work}

Several analytical methods including OM, SEM-EDX, $\mu \mathrm{RS}, \mu \mathrm{ATR}$-FTIR and pXRD were employed to shed light on the pigments, materials and structure of the paint layers of this copy of Raphael's Transfiguration. OM observation of the cross sections revealed the presence of a red-brown ground layer and different pictorial layers as well as an absence of varnish. The thickness of the underpainting and the pictorial layers varies between the different colors applied. In this respect, a thick underpainting layer mainly composed of white lead pigment is observed in the drapery of some figures as the artist searched for specific coloring (light colors) and saturation effects. The underpainting in the rest of the samples from the brown and blue-sky areas is difficult to distinguish. The combination of complementary techniques confirmed the presence of iron oxides (hematite and goethite), cerussite, hydrocerussite with traces of clay minerals and aluminosilicate mineral, gypsum or anhydrite, calcite and baryte on the ground layer. This red-brown ground was usually used by artists in Europe during the sixteenth-eighteenth centuries, including painting. $\mathrm{Mn}$ and $\mathrm{C}$ black pigments were also found in the painting, which were usually aimed at darkening the tones of the drapery as well as the colorless powdered glass. The literature available has also reported on the presence of powdered glass used to speed up the drying of the paint in some paintings by Raphael and other European artists from the fifteenth-seventeenth centuries. All the pigments and fillers identified (cerussite, hydrocerussite, goethite, hematite, lepidocrocite, red lake, cinnabar, lapis lazuli, smalt, lead tin yellow, carbon and traces of bone blacks were available in the sixteenth-seventeenth centuries in
Europe. The ${ }^{14} \mathrm{C}$ AMS revealed that the canvas sample had a radiocarbon data consistent with the second half of the fifteenth century and the first quarter of the seventeenth century (with a 95\% confidence level).

Although the focus of the present study was to improve the analytical methodology in the Cultural Heritage field to better understand the artist's palette, the structural and analytical results will provide us with information to explore the authorship of the copy or the school that executed it.

\section{Abbreviations \\ OM: Optical microscopy; SEM-EDX: Scanning electron microscopy and Energy-dispersive X-ray spectroscopy; $\mu$ ATR-FTIR: Micro-attenuated Total Reflectance Fourier Transform Infrared Spectroscopy; $\mu$-RS: MicroRaman spec- trometry; XRF: X-ray fluorescence spectroscopy; XRD: X-ray Powder Diffraction; ASM: Accelerator Mass Spectrometry.}

\section{Acknowledgements}

We thank the owner of the painting Mr. F. Fernandez Fábregas and the research group FQM-338 (University of Granada) for letting us use its facilities. We also thank Maria José Campos for the preparation of the cross-section samples.

\section{Authors' contributions}

All the authors belong to the research team Unit of Non-Invasive Analytical Techniques Unit (University of Granada, Spain) funded by EQC2018-004952-P and A-HUM-164-UGR18 Projects, currently active. All the authors read and approved the final manuscript. EM: Professor of Analytical Chemistry applied under Cultural heritage at the Department of Analytical chemistry of the University of Granada, Spain. The author contributed to the examination of the Transfiguration of Christ, using photography, SEM-EDX, and performed the $\mu \mathrm{RS}$ and $\mu \mathrm{ATR}$-FTIR analyses; and contributed to the interpretation of the datasets, contextualization of data, and writing of the manuscript. RB: Full Professor of Analytical Chemistry at the Department of Analytical chemistry of the University of Granada, Spain. The author contributed to the examination of the painting, sampling, contextualization of the painting, elaboration of tables and figures, contextualization of data, and participated in the interpretation of the datasets. The author read and approved the final manuscript. JDM-R: Professor of Mineralogy at the Department of Mineralogy and Petrology of the University of Granada, Spain. The author provided the interpretation of the mineralogical data. GCh: Professor of Mineralogy Applied under Cultural Heritage at the Department of Earth Sciences of the University of Torino, Italy, Chief Scientist at the Getty Conservation Institute in Los Angeles, CA (director of the Science department for 11 years). The author works now as a freelance consultant in the field of Conservation of Cultural heritage. The author read and approved the final manuscript. PS: Scientist at the SETI Institute and founder of eXaminart LLC. The author develops miniature X-ray analytical instruments for Space exploration ((e.g. the NASA CheMin XRD instrument inside the Curiosity Mars rover) and portable instruments dedicated to cultural heritage. The author contributed to the examination of the Transfiguration of Christ, using pXRD. The author read and approved the final manuscript. JLV: Full Professor of Analytical Chemistry at the Department of Analytical chemistry of the University of Granada, Spain. The author contributed to the Transfiguration of Christ, using photography, SEM-EDX; contributed to the interpretation of the datasets, the contextualization and revision of data. All authors read and approved the final manuscript.

\section{Funding}

The present work has received financial support from Non-Invasive Analytical Techniques Unit EQC2018-004952-P and research project FEDER/Junta de Andalucía-Consejería de Economía y Conocimiento/ A-HUM-164-UGR18.

\section{Availability of data and materials}

The datasets used and/or analyzed during the current study are available from the authors upon request. 


\section{Declarations}

\section{Competing interests}

The authors declare that they have no competing interests.

\section{Author details}

${ }^{1}$ Department of Analytical Chemistry, University of Granada, Fuentenueva s/n, 18071 Granada, Spain. ${ }^{2}$ Department of Analytical Chemistry, University of Granada, Fuentenueva s/n, 18071 Granada, Spain. ${ }^{3}$ Department of Mineralogy and Petrology, University of Granada, Fuentenueva s/n, 18071 Granada, Spain. ${ }^{4}$ Getty Conservation Institute, (retired) Via S. Tommaso 29, 10121 Torino, Italy. ${ }^{5}$ eXaminArt LLC, Mountain View, CA, USA.

Received: 13 July 2021 Accepted: 29 October 2021

Published online: 11 November 2021

\section{References}

1. Musílek L, Čechák T, Trojek T. X-ray fluorescence in investigations of cultural relics and archaeological finds. Appl Radiat Isotopes. 2012;70(7):1193-202. https://doi.org/10.1016/j.apradiso.2011.10.014

2. Franquelo ML, Duran A, Herrera LK, De Haro MJ, Pérez-Rodríguez JL. Comparison between micro-Raman and micro-FTIR spectroscopy techniques for the characterization of pigments from Southern Spain Cultural Heritage. J Mol Struct. 2009;924:404-12. https://doi.org/10.1016/j.molst ruc.2008.11.041

3. Bikiaris D, Daniilia S, Sotiropoulou S, Katsimbiri O, Pavlidou E, Moutsatsou $\mathrm{AP}$, Chryssoulakis Y. Ochre-differentiation through micro-Raman and micro-FTIR spectroscopies: application on wall paintings at Meteora and Mount Athos. Greece Spectrochim Acta A. 2000;56(1):3-18. https://doi. org/10.1016/S1386-1425(99)00134-1.

4. Želinská J, Kopecká I, Svobodová E, Milovská S, Hurai V. Stratigraphic EM-EDS, XRF, Raman and FT-IR analysis of multilayer paintings from the Main Altar of the St. James Church in Levoča (Slovakia). J Cult Herit. 2018;33:90-9. https://doi.org/10.1016/j.culher.2018.03.006.

5. Vaggelli G, Cossio R. $\mu-X R F$ analysis of glasses: a non-destructive utility for cultural heritage applications. Analyst. 2012;137(3):662-7. https://doi.org/ 10.1039/C1AN15518K

6. Manzano E, Rodríguez-Simón LR, Navas N, Checa-Moreno R, RomeroGámez M, Capitan-Vallvey LF. Study of the GC-MS determination of the palmitic-stearic acid ratio for the characterisation of drying oil in painting: La Encarnación by Alonso Cano as a case study. Talanta. 2011;84(4):1148-54. https://doi.org/10.1016/j.talanta.2011.03.012.

7. Manzano E, Navas N, Checa-Moreno R, Rodríguez-Simón LR, CapitánVallvey LF. Preliminary study of UV ageing process of proteinaceous paint binder by FT-IR and principal component analysis. Talanta. 2009;77(5):1724-31. https://doi.org/10.1016/j.talanta.2011.03.012.

8. Fontana D, Alberghina MF, Barraco R, Basile S, Tranchina L, Brai M, Gueli A, Troja SO. Historical pigments characterisation by quantitative $\mathrm{X}$-ray fluorescence. J Cult Herit. 2014;15(3):266-74. https://doi.org/10.1016/j. culher.2013.07.001.

9. Gutman RN, Price BA, Sutherland K, Lins AP, Newman R, Wang P, Wang T, Tague TJ. Salvator Mundi: an investigation of the painting's materials and techniques. Herit Sci. 2020;8:1-12. https://doi.org/10.1186/ s40494-020-00382-3.

10. Martínez-Domingo MA, Valero EM, Nieves JL, Blanc MR, Manzano E, Vilchez JL. Multifocus HDR VIS/NIR hyperspectral imaging and its application to works of art. Opt Express. 2019;27(8):11323-38. https://doi.org/10. 1364/OE.27.011323.

11. Eberhardt K, Stiebing C, Matthäus C, Schmitt M, Popp J. Advantages and limitations of Raman spectroscopy for molecular diagnostics: an update. Expert Rev Mol Diagn. 2015;15(6):773-87. https://doi.org/10.1586/14737 159.2015.103674412)

12. Martin-Ramos JD, Zafra-Gómez A, Vílchez JL. Non-destructive pigment characterization in the painting Little Madonna of Foligno by X-ray Powder Diffraction. Microchem J. 2017;134:343-53. https://doi.org/10.1016/j. microc.2017.07.001.
13. Vilchez-Quero JL, Zafra-Gomez A, Martin-Ramos JD, Chiari G. Analytical Study of "The Little Madonna of Foligno". Ed. UGR. ISBN: 978-84-1692924-5. 14th of February 2017.

14. Martin Ramos JD, Vilchez JL, Chiari G. A new procedure elemental maps by combining XRF data to other types of images. Art'17 12th Conference Torino 2017.

15. Chiari G, Sarrazin P, Martin JD, Vilchez JL. Combined use of portable XRD/ XRF and SmART_scan to produce pigments maps. International Symposium on Archaeometry, Lisbon, 18th-22nd May 2020.

16. Chiari G, Sarrazin P, Heginbotham A. Non-conventional applications of a noninvasive portable X-ray diffraction/fluorescence instrument. Giacomo Chiari. Philippe Sarrazin and Arlen Heginbotham. Appl Phys A. 2016;122(11):1-17. https://doi.org/10.1007/s00339-016-0521-x.

17. Preimesberger R. Paragons and Paragone: Van Eyck, Raphael, Michelangelo, Caravaggio. Bernini: Getty Publications; 2011.

18. https://www.museodelprado.es/coleccion/obra-de-arte/transfiguraciondel-seor/eed62f0d-1fb1-44c6-af98-96301160b7f2. Accessed 01 July 2021.

19. https://autillodecampos.blogspot.com/2013/04/una-copia-italiana-derafael-sanzio-en.html. Accessed 01 July 2021.

20. https://www.academiacolecciones.com/pinturas/inventario.php?id= 0570. Accessed 01 July 2021.

21. Burgio L, Clark RJ. Library of FT-Raman spectra of pigments, minerals, pigment media and varnishes, and supplement to existing library of Raman spectra of pigments with visible excitation. Spectrochim Acta A. 2001:57(7):1491-521. https://doi.org/10.1016/S1386-1425(00)00495-9.

22. Bell IM, Clark RJ, Gibbs PJ. Raman spectroscopic library of natural and synthetic pigments (pre- $\approx 1850$ AD). Spectrochim Acta A. 1997:53(12):215979. https://doi.org/10.1016/S1386-1425(97)00140-6.

23. IRUG database.http://www.irug.org/search-spectral-database. Accessed 21 June 2021

24. Martin-Ramos JD, XPowder $X^{\mathrm{TM}}$, A Software Package for XRPD. Lgl. Dp. GR 780-2016, 2016 (ISBN 978-84-16478-87-3. analysis.www.xpowder.com. Accessed 01 July 2021.

25. Hajdas I, Cristi C, Bonani G, Maurer M. Radiocarbon. 2014;56(2):637-43. https://doi.org/10.2458/56.17757.

26. García MDG, de Celis MJ. Evolución de las preparaciones en la pintura sobre lienzo de los siglos XVI y XVII en España. Boletín del Museo del Prado. 2010:28(46):39-59.

27. Roy A, Spring M, Plazzotta C. Raphael's early work in the National Gallery: paintings before Rome. Nat Gallery Tech Bull. 2004;25:4-35. https://www. jstor.org/stable/42616174

28. Spring, M. Raphael's materials: Some new discoveries and their context within early sixteenth-century painting. Raphael's Painting Technique: Working Practices before Rome. 2004, p. 75-84

29. Higgitt C, White R. Raphael's early work in the National Gallery: analyses of paint media: new studies of Italian painting of the fifteenth and sixteenth centuries. Tech Bull. 2005:26:4-35.

30. Spring M. Colourless powdered glass as an additive in fifteenth-and sixteenth-century European paintings. Nat Gallery Tech Bull. 2012;33:426. https://www.jstor.org/stable/42616272

31. Lutzenberger $\mathrm{K}$, Stege $\mathrm{H}$, Tilenschi $\mathrm{C}$. A note on glass and silica in oil paintings from the 15th to the 17th century. Natl Gallery Tech Bull. 2010:11(4):365-72. https://doi.org/10.1016/j.culher.2010.04.003.

32. Dunkerton J, Spring M. The development of painting on coloured surfaces in sixteenth-century Italy. Stud Conserv. 1998;43(sup 1):120-30. https://doi.org/10.1179/sic.1998.43.Supplement-1.120.

33. Spring M, Mazzotta A, Roy A, Billinge R, Peggie D. Painting practice in Milan in the 1490s: the influence of Leonardo. Natl Gallery Tech Bull. 2011;32:78-112. https://www.jstor.org/stable/42616229

34. Eikema-Hommes M. Discoloration or Chiaroscuro? An Interpretation of the Dark Areas in Raphael's" Transfiguration of Christ". Simiolus: Netherlands Quarterly for the History of Art, 2000; 28(12):5-43. doi: https://doi. org/10.2307/3780957

35. Jonynaite D, Senvaitiene J, Beganskiene A, Kareiva A. Spectroscopic analysis of blue cobalt smalt pigment. Vib Spectrosc. 2010;52(2):158-62.

36. Kirby JO, Spring M, Higgitt $C$. The technology of red lake pigment manufacture: study of the dyestuff substrate. Natl Gallery Tech Bull. 2005;26:7187. https://doi.org/10.1016/j.vibspec.2009.12.005.

37. Shillito LM, Almond MJ, Nicholson J, Pantos M, Matthews W. Rapid characterisation of archaeological midden components using 
FT-IR spectroscopy, SEM-EDX and micro-XRD. Spectrochim Acta A. 2009;73(1):133-9. https://doi.org/10.1016/j.saa.2009.02.004.

38. Svobodová E, Bosáková Z, Ohlídalová M, Novotná M, Němec I. The use of infrared and Raman microspectroscopy for identification of selected red organic dyes in model colour layers of works of art. Vib Spectrosc. 2012;63:380-9. https://doi.org/10.1016/j.vibspec.2012.09.003.

39. Stuiver M, Polach HA. Discussion reporting of $14 \mathrm{C}$ data. Radiocarbon. 1977;19(3):355-63. https://doi.org/10.1017/S0033822200003672.

\section{Publisher's Note}

Springer Nature remains neutral with regard to jurisdictional claims in published maps and institutional affiliations.

\section{Submit your manuscript to a SpringerOpen ${ }^{\circ}$ journal and benefit from:}

- Convenient online submission

- Rigorous peer review

- Open access: articles freely available online

- High visibility within the field

- Retaining the copyright to your article

Submit your next manuscript at $\boldsymbol{\nabla}$ springeropen.com 